\title{
En busca de un lugar en el mundo: viajeros latinoamericanos en la Europa del siglo XIX'
}

CARLOS SANHUEZA

\begin{abstract}
Resumo: O presente trabalho examina experiências de viajantes latino-americanos pela Europa durante o século XIX. O objetivo é analisar a posição que adotaram, discutindo e colocando em dúvida o pertencimento da América ao mundo ocidental. Aqui se postula que a viagem de intelectuais à Europa mostra as complexidades do processo de reorganização pós-colonial daquele século.
\end{abstract}

Abstract: This article examines experiences of Latin American travellers in Europe in $19^{\text {th }}$ century. The objective is to analyze the position that these travellers took discussing and putting in doubt the relationship from America to the western world. Here it is postulated that the travel of intellectuals to Europe shows the complexities of the postcolonial reorganization process.

Palavras-chave: Viajantes latino-americanos. Ocidente. Imagem da Europa.

Key words: Latin-American travellers. Occident. Image of Europe.

Desde hace un tiempo que se viene afirmando en qué sentido nociones como Oriente u Occidente o lugares como América, Europa o Asia, no han conformado tan sólo entidades geográficas sino también formas de representación cultural. Ello viene a destacar cómo ciertos espacios no solamente han sido utilizados como referencias geopolíticas sino también en tanto formas de situarse en el mundo. De ahí que se preste atención a los discursos, a las maneras a partir de las cuales se han concebido tales espacios, a las trazas que han definido identidades, a las perspectivas que han

1 Este artículo forma parte de un proyecto de investigación Fondecyt - Posdoctoral № 3050084 referido a viajeros latinoamericanos en Europa durante el siglo XIX. El autor agradece a la Comisión Nacional de Investigación Científica y Tecnología de Chile (CONICYT) el apoyo prestado.

Instituto de Estudios Humanísticos Abate Juan Ignacio Molina, Universidad de Talca, Chile.

Estudos Ibero-Americanos. PUCRS, v. XXXIII, n. 2, p. 51-75, dezembro 2007 
localizado pueblos asociados a sus paisajes, a los argumentos que han justificado la existencia de márgenes y centros. ${ }^{2}$ El presente artículo busca aportar en tales debates a partir del estudio de un conjunto de relatos de viajes escritos por latinoamericanos durante el siglo XIX en sus travesías por Europa. A partir de allí se discute en qué medida América Latina se fue configurando como un espacio geocultural desde un proceso de inserción en el mundo, no tan sólo creado y diseñado por la intelectualidad europea. En particular se aborda mediante qué procedimientos, y a partir de qué vinculaciones con su tiempo histórico, tales viajeros definieron con posterioridad a la Emancipación de España un espacio simbólico que los situaba frente a las nociones de Viejo y Nuevo Mundo, de Oriente y Occidente.

\section{El lugar de América Latina}

Ya desde los clásicos escritos de Antonello Gerbi en 1955 se ha venido enfatizado el papel que los propios americanos tuvieron en las concepciones de lo americano y de lo europeo. Ello busca destacar hasta qué punto la noción del Viejo Mundo, o de Occidente, no se originó tan sólo mediante un flujo unidireccional de influencias, filosofías, visiones, etc. desde Europa hacia América sino, también, a partir de lo construido en el Nuevo Mundo: a través de un conjunto de reapropiaciones, de ciertas lecturas, e incluso desde acomodos y negaciones de lo recibido. De allí que Gerbi no aborde exclusivamente las nociones de un Buffón o de un De Pauw sobre la inferioridad americana, sino también las reacciones americanas: desde los jesuitas americanos expulsos del siglo XVIII, pasando por intelectuales decimonónicos tanto del norte como del sur del continente. ${ }^{3}$

Leopoldo Zea ha destacado el esfuerzo que las élites ilustradas del siglo XIX realizaron inscribiendo a Hispanoamérica en el movimiento de la historia universal. En primer lugar, tal y como también lo afirma el propio Gerbi, América contesta las ofensas, prejuicios e ignorancia de Europa: la fauna, la flora, el suelo y la historia del Nuevo Mundo son reevaluadas y revalidadas por los habitantes criollos. Es a partir de tal privilegio de lo propio como el Nuevo Mundo logra reclamar un puesto entre las culturas. Esta

2 Respecto a cuestionamientos relativos a oriente y occidente ver BHABHA, 1994; y SAID, 1978. En relación al concepto de representación ver CHARTIER, 2002; y RICOEUR, 2002.

3 GERBI, 1993. 
demanda de reconocimiento no sólo se expresó como una mera defensa de un amor propio mancillado sino que, desde un comienzo, implicó el problema de la identidad, así como la relación de lo americano con sus raíces europeas. Este intento de inserción de América Latina en la historia universal llegó a ser conflictiva: contradictoria, entre lo que se deseaba ser y lo que se rechazaba; esperanzadora, a partir de lo que se vislumbraba y lo que se dejaba atrás. ${ }^{4}$

En la década de los noventa del siglo XX nuevos trabajos han revitalizado la cuestión del puesto de América Latina en el mundo, en especial a partir del análisis de la inserción del subcontinente en la modernidad. De esta forma, Enrique Dussel pone en tela de juicio una modernidad mitologizada de raíces meramente europeas, haciendo hincapié en las contribuciones de los excluidos barbaros, dudando del origen exclusivamente eurocéntrico de dicha inclusión, tal y como ciertos autores, por ejemplo James Blaut, lo sustentan. ${ }^{5}$ En este sentido, el aporte de los llamados Estudios Postcoloniales y Subalternos, en autores como Santiago CastroGómez, Fernando Coronil y Walter Mignolo, junto con la importante contribución de Aníbal Quijano e Immanuel Wallerstein, han puesto bajo nuevas luces la discusión respecto de los sentidos y aspectos de la búsqueda latinoamericana de un lugar en el mundo moderno. ${ }^{6}$

Santiago Castro-Gómez recalca de qué manera América Latina ha sido constituida como objeto de saber desde las mismas sociedades latinoamericanas a partir de metodologías occidentales como el enciclopedismo, el romanticismo utópico, la hermenéutica, etc. Según Castro-Gómez, de lo que se trata no es tanto de una copia de modelos foráneos o simple imitación, sino más bien de una apropiación histórica de los discursos intelectuales en los contextos locales de América Latina así como de la conformación de saberes de auto-observación social. ${ }^{7}$

Walter Mignolo ha discutido cómo la perspectiva europea de la construcción de un imaginario del mundo moderno occidental no sólo fue realizada por una "interioridad" (letrados, pensadores) o una "exterioridad" (Asia, África, América), sino también a partir de las "respuestas" que desde los márgenes de la civilización se ofrecían al Viejo Mundo. Estas respuestas, sin embargo, no se han

Ver: ZEA, 1976, 1972 y 1992.

DUSSEL, 1995 y 1999; BLAUT, 1993.

6 CASTRO-GÓMEZ, 1996 y 1998; CORONIL, 1996; MIGNOLO, 1993, 1998 у 2000; QUIJANO, 1998; WALLERSTEIN, 1974-1989.

7 CASTRO-GÓMEZ, 1998. 
estudiado lo suficiente pues Europa siempre ha concebido el por Wallerstein denominado "sistema-mundo moderno" desde su propio imaginario, pero no desde el imaginario conflictivo que surgió desde la periferia. Según el citado Mignolo, la idea de "hemisferio occidental" (que sólo aparece mencionada como tal en la cartografía a partir de finales del siglo XVIII), estableció ya una posición ambigua. América era la diferencia de Europa, pero al mismo tiempo su mismidad. América era otro hemisferio, pero era occidental. Era distinta de Europa, pero ligada a ella y, sin embargo, diferente de África y Asia, continentes y culturas que no formaban parte de la definición del hemisferio occidental. Dicha ambigüedad provocó una encrucijada, una tensión entre lo que se consideraba "lo propio" y lo que se consideraba "ajeno". Esta situación en ningún caso pudo solucionarse en el período colonial, tornándose conflictiva con posterioridad a la emancipación de España y Portugal. ${ }^{8}$

Recientemente Marcello Carmagnani ha analizado la relación conflictiva de América Latina en tanto parte del mundo occidental. En tal cometido estudia aquellos procesos que han favorecido o, por el contrario, entrabado la convergencia entre las áreas latinoamericanas y europeas y entre éstas y los demás continentes, en un espectro temporal que va desde 1492 hasta nuestros días. Su objetivo central radica en mostrar y subrayar las interacciones económicas, sociales, políticas y culturales entre ambos mundos puesto que, según Carmagnani, fueron justamente dichas interacciones las que instaron a los latinoamericanos a "elegir determinadas opciones colectivas y convertirse en sujetos activos en el proceso de occidentalización". 9

Cabe destacar que un elemento que rescata Carmagnani es cierta "matriz" cultural que vincula a América Latina con Europa. Según tal autor, el hecho de que el subcontinente participe del mundo cristiano le ha otorgado ciertas ventajas, mismas que no poseen o gozan los musulmanes, los animistas africanos o los hindúes. Por otro lado, Carmagnani afirma que la

occidentalización de las áreas latinoamericanas se configura [...] como el producto de la participación de todos los actores que generan fuerzas dinámicas, ya sea de aquellos que desde Europa se proyectan hacia el contexto latinoamericano, ya sea de los que se vuelcan a la escena internacional desde el subcontinente. ${ }^{10}$

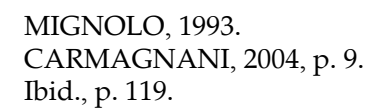


Habría que asumir que entre estos actores que "generan fuerzas dinámicas" Carmagnani no incluye a aquellos grupos que no se vinculan con el mundo cultural europeo, como los indios, los africanos o los mestizos. En efecto, según Carmagnani, la occidentalización, en este sentido, correspondería a un esfuerzo de la élites criollas, más que al conjunto de la sociedad. Son estos actores quienes poseen la "matriz" adecuada y los que en definitiva logran insertarse, vía comercio internacional y apropiación de ideas, en el mundo europeo. De ahí que Carmagnani concentre su estudio prácticamente sólo en aquel grupo sin advertir las dificultades, rechazos o críticas de aquellos que no hacían parte de tal matriz $u$ horizontes culturales.

Al revisar la cuestión de la posición cultural de América Latina ante Europa se advierte cómo, en el estudio de dicha relación, no se ha abordado el impacto que la literatura de viajes escrita por latinoamericanos llegó a tener sobre la conformación de una representación americana del mundo europeo. Hasta ahora no se han investigado suficientemente de qué forma las élites latinoamericanas concibieron su relación con el Viejo Mundo desde la experiencia de viajes en Europa: en qué sentido se alejaron o acercaron de sus raíces europeas, en qué medida llegaron a abandonar el modelo del Viejo Continente para construirse uno nuevo, esta vez americano. Por otro lado, si se considera que un criterio de legitimidad que marcó al siglo XIX fue el empírico, es posible hacerse una idea del eco que las relaciones de viajes pudieron haber tenido en el público latinoamericano. Desde ese punto de vista resulta importante abordar tales textos puesto que fueron los únicos que retrataron una Europa "directa", en el sentido que tales escritos se validaban al ubicarse desde lo "realmente visto" y no a partir de un escritorio americano o unas fantasías emergiendo desde el Nuevo Mundo. Finalmente, tampoco se ha reflexionado en relación a las evaluaciones, críticas y hasta oposiciones que los latinoamericanos realizaron del mundo moderno europeo. El estudio de los viajes de latinoamericanos en Europa, hasta ahora, más bien ha destacado el aspecto imitativo de dichos periplos sin abordar en qué sentido lo observado por estos viajeros reformuló, reforzó o hasta negó lo que el Viejo Continente representaba para el Nuevo Mundo. En lo que sigue se abordan tales cuestiones en el intento de aportar al debate hasta ahora desarrollado. ${ }^{11}$

11 Respecto del viaje de latinoamericanos a Europa véase NÚÑEZ, 1990; MARTÍNEZ, 2001; FEY/RACINE, 2000; SANHUEZA, 2004, 2005a, 2005b, 2006a y 2006b. Respecto del papel imitativo del viaje a Europa ver los citados textos de FEY/RACINE y 


\section{El nuevo mundo y su destino occidental}

Antonello Gerbi en La Disputa del Nuevo Mundo aborda lo que él denomina el "feliz destino de occidente" de América. Según Gerbi, el Nuevo Mundo desde muy temprano se yergue como el heredero de Europa; como la nueva civilización que se veía florecer al otro lado del Atlántico. ${ }^{12}$

Esta noción de América empuñando el cetro del mundo, si bien se vio reforzada por el triunfo de la revolución norteamericana de fines del siglo XVIII, posee orígenes bastante remotos, ubicada por el historiador milanés "coetánea de la conquista misma del continente". En efecto, el aparecimiento de un nuevo continente generó un conjunto de discusiones y polémicas en pos de encontrarle un lugar entre las culturas conocidas. La noción del traslatio imperii, esto es, la marcha de la civilización y la monarquía universal de oriente a occidente, se traducía en un plano geográfico, de Este a Oeste: 13

de aquellas viejas teorías historiográficas sacadas de los libros de Daniel y Polibio y de la poesía de Hesíodo y de Ovidio, que ordenaban la historia universal sobre los esquemas de las cuatro monarquías o de las seis edades del mundo, y daban razón plena y fatal de la grandeza y decadencia y de la cíclica sucesión de los imperios. ${ }^{14}$

Esta reinterpretación de la Antigüedad confluía con la tradición judeo-cristiana:

la autoridad de la Biblia confirmaba que de Oriente habían llegado la Revelación y las leyes del vivir civilizado y del hombre mismo [...] Para el europeo, fueron Oriente el Edén y el monte Sinaí, Jerusalén y la tierra de Canaán. [...] Las Cruzadas mismas, por lo demás, habían estimulado la convicción de que la historia procedía de Oriente a Occidente. ${ }^{15}$

De modo que, siguiendo a Gerbi, todo tendía a imponer la visión del camino de la historia de Oriente a Occidente y a facilitar, por lo tanto, la inclusión de las Indias Occidentales recién descubiertas en esa construcción historiográfica. Es posible afirmar que por lo menos hasta el siglo XVIII, pocos dudaban del naturae

MARTÍNEZ. Ver además GONZÁLEZ, 2003 y 2004. Véase también VICUÑA, 2001, p. 104.

12 GERBI, 1993, p. 160-180. Véase además PIETRI, 1992, p. 69-82.

13 GERBI, 1993, p. 161.

14 Ibid., p. 162.

15 Ibid., p. 164. 
cursus que veía al Nuevo Mundo como una prolongación de la historia del Viejo Continente.

Importante resulta destacar cómo la inclusión de América en una nueva perspectiva que alteraba la visión tripartita entre Europa, África y Asia no suponía tan sólo una distribución meramente territorial sino más bien una organización cultural del mundo. Tal como lo afirma Edmundo O'Gorman, si bien los espacios geográficos aparecen como entidades territoriales, trascienden el orden puramente geográfico, individualizándose cada entidad desde el punto de vista moral e histórico. De allí el empeño puesto a fin de otorgarle un ser a las tierras recién descubiertas al momento de percatarse que un nuevo territorio entraba en la escena mundial. En efecto, a pesar de negarles a los habitantes originarios de América un estatus equiparable al hombre europeo, se consideraba a dichos hombres como parte de la vida humana. En otros términos, al margen de las jerarquías que evidenciaban la superioridad de Europa, se integraba a los indígenas americanos en el marco de los pueblos ya conocidos por el Viejo Mundo. ${ }^{16}$

La designación de América como Nuevo Mundo permitió abrir la posibilidad de que dicho continente llegara a constituir una nueva Europa. Sin embargo, de ello no se seguía que el nuevo continente se ubicaba en igualdad de condiciones respecto de Europa: según el citado O'Gorman, el Viejo Continente - sede de la cultura y asiento de la Cristiandad - "asumía la representación del destino inmanente y trascendente de la humanidad, y la historia europea era el único devenir humano preñado de auténtica significación". ${ }^{17}$ De lo anterior se sigue que las tierras descubiertas no conformaron meramente la instalación de un ente ya constituido en el panorama de la humanidad, antes bien: se originó como un proceso inventivo de un ser hecho a imagen y semejanza de su inventor.

La condición de dependencia de América respecto de su mentor Europa trajo una disyuntiva sobre el ser americano. En un sentido, América era una nueva Europa lo que de alguna manera cumplía la promesa universalista de la cultura occidental. En otro aspecto, América era la alteridad, lo que permitía que el Viejo Mundo se diferenciase, reforzando su condición de faro cultural y punto de referencia. De modo que América era, al mismo tiempo, "lo mismo" y "lo otro" respecto de Europa: la realización de un designio, como la diferencia que la negaba. De alguna extraña

16 O'GORMAN, 2004, p. 159.

17 Ibid., p. 148 y 152. 
forma América se ubicaba en el mundo como la quimera y la pesadilla de un sueño occidental.

Walter Mignolo destaca, siguiendo entre otros a Quijano y Wallerstein, en qué sentido las nociones de "Indias Occidentales", "Nuevo Mundo" y más tarde "América" constituyeron las palabras claves utilizadas por el occidentalismo para expandirse. Según Mignolo dicha imposición occidentalista, que instalaba las tierras recién descubiertas en el escenario mundial, conformó un discurso de anexión de la diferencia más que la creación de un opuesto irreducible tal y como lo ha señalado Edward Said a propósito de la relación de Oriente con Europa. Tres grandes momentos históricos justificaron la incorporación de América a los relatos occidentalistas: aquellos que en un comienzo legitimaron la anexión y conversión de los indios (Bartolomé de las Casas); a partir de la conversión en el siglo XVIII de los "salvajes" y "caníbales" alejados en el espacio a "primitivos" alejados en el tiempo (Joseph Francois Lafitau) y desde que a fines del siglo XVIII y comienzos del XIX se repiensa el Nuevo Mundo en torno al progreso de la investigación científica (Alexander von Humboldt). En cada momento América unía su destino inevitable al modelo occidental. ${ }^{18}$

Ahora bien, esta imbricación de América con Europa, desde un destino compartido, sufrió un brusco cambio a partir del siglo XVIII. En efecto, el llamado Siglo de las Luces trajo un cisma que alteró para siempre la posición del Nuevo Mundo en el marco de la cultura occidental.

Interesante resulta advertir cómo participa el filósofo G. W. F. Hegel en esta reinscripción de América ocurrida en la centuria dieciochesca. Si bien en su Philosophie der Weltgeschichte (Filosofía de la Historia Universal), Hegel menciona que la historia universal se desplaza de Oriente a Occidente, de ninguna manera aquello implicaba una inclusión "natural" del Nuevo Mundo en la historia universal de Occidente. El filósofo suevo no sólo emite un juicio total y severo sobre América al considerarla condenada por su inmadurez a un papel secundario en la historia, sino que también introduce una cuña que separó a ambas Américas. ${ }^{19}$

En un sentido, las deducciones de Hegel, en relación a la existencia de diferentes continentes y hemisferios, llegó a conformar un mapa imaginario de ejes marcados por sus características antitéticas. Si bien Hegel no fue el primero en deducir diferencias entre posiciones geográficas disímiles, sí llegará a tener una notable in-

18 MIGNOLO, 1995, p. 315-334; y 1998.

19 HEGEL, 1972. 
fluencia posterior. El mundo nuevo y el antiguo, de este modo, se separaban al ser parte de las divisiones de la tierra. Tal como lo comenta Gerbi a propósito de lo afirmado por Hegel, todo indicaba la existencia de dos entidades geográfico-culturales totalmente apartadas: un Viejo Mundo curvo como una herradura alrededor del Mediterráneo, el Nuevo alargado de Norte a Sur; el Viejo Mundo perfectamente separado en tres partes bien articuladas e integradas, el Nuevo Mundo por el contrario mal cortado e incompleto. Estas características imprimían un sello a ambos espacios: lo nuevo devenía en inmadurez y debilidad. El calificativo de inmaduro y joven poseía un innegable cariz negativo: América representaba lo no sistematizado; lo no perfectamente conocido; lo aún no completo, pleno o desarrollado (tanto natural, como sociopolítico). En Hegel, la inmadurez del Nuevo Mundo se extendía en múltiples planos y esferas: América no era relativamente nueva, sino totalmente nueva, en el sentido de su características físicas y espirituales. ${ }^{20}$

En otro aspecto, si bien Hegel reconocía la inferioridad de todo el continente americano respecto de Europa, dada su condición de "pueblos sin historia" (Völker ohne Geschichte), se abría a la posibilidad de establecer diferencias entre una América sajona y una latina. En efecto, Hegel destaca cómo el Nuevo Mundo se observaba dividido en dos partes en términos geográficos, lo que según él tendía a favorecer al norte respecto del sur al poseer la primera una mayor amplitud. Lo anterior, al mismo tiempo, también implicaba dos desarrollos disímiles. En un sentido, mientras en America del Norte se observaba la prosperidad (das Gedeihen), orden cívico y sólida libertad, en América del Sur por el contrario, las repúblicas se habían construido sobre la base de una violencia militar. Otro aspecto que diferenciaba a ambas Américas no solamente era la estructura política de sus instituciones, sino también su religión: Sudamérica se advertía católica, América del norte, protestante. Lo anterior, según Hegel, llegó a ser decisivo: mientras los protestantes, que habían arribado al Nuevo Mundo tras la búsqueda de una libertad religiosa que en Europa no existía, mostraban una confianza en el individuo, la exigencia, la tranquilidad, la justicia cívica y la libertad, los católicos - por el contrario - no

20 GERBI, op., cit. , p. 536-538. Ver: HEGEL, op., cit., p. 106. Originalmente la cita afirma: "Pero estas partes del mundo no son solamente nuevas sino totalmente nuevas en relación a su constitución física y espiritual" " Aber diese Weltteile sind nicht nur relativ neu, sondern überhaupt neu, in Ansehung ihrer physichen und geistigen Beschaffenheit"). Respecto del mito de la juventud americana véase: PIETRI, op. cit., p. 217218. 
ponían su confianza en el individuo, dominando entre ellos sólo la violencia y la desigualdad. Finalmente, en gran medida se explicaba las disimilitudes entre una y otra América dada la entrada de Europa a ambos espacios: América del Norte había sido colonizada, por su parte Sudamérica, conquistada. En el primer lugar se había impuesto los estados libres, en el segundo, la opresión y el dominio despótico. ${ }^{21}$

De todas estas divergencias y posiciones encontradas Hegel trazó una frontera entre ambas Américas. Sólo a la porción protestante, colonizada, próspera y de instituciones sólidas le estaba permitido desarrollarse y ostentar el título de "país del futuro" (Land der Zukunft). Dicho desarrollo de América del Norte se habría de construir sobre la base de un enfrentamiento entre la América Sajona y la Hispana. Hegel llegó a vaticinar que dicho conflicto llegaría a conformar en el futuro el centro de gravedad de la historia universal y, por ende, de Occidente. En definitiva, Hegel había expulsado a América Latina del paraíso occidental y de su destino en la historia universal.

En lo que se sigue se aborda en qué sentido, y a partir de que supuestos, este exilio del mundo occidental influyó en el periplo latinoamericano a Europa durante el siglo XIX.

\section{Viajeros latinoamericanos en Europa ${ }^{22}$}

El viaje de hispanoamericanos a Europa sufrió un cambio drástico a partir del proceso de Emancipación de España, como de la construcción de los nuevos estados nacionales que dicha cesura supuso. Si bien es posible advertir las huellas de los traslados de América al Viejo Mundo, previo a tales cambios políticos, éstos se situaron siempre en el marco común de la pertenencia al Imperio Español. En efecto, ni los hijos de los criollos enviados a estudiar y a participar de la Corte Madrileña, ni posteriormente los llamados precursores de la Independencia en sus recorridos por Europa aún a pesar de que escribieron algunos relatos de viajes - produjeron un género literario de viajes o una literatura sobre Europa. No existía un proyecto ideológico propio que hubiese podido motivar una configuración criolla de Europa. El colono se representaba a sí mismo dentro de los márgenes burocráticos y mentales del Imperio. La relación súbdito-corte hacía difícil la

21 Ibid., p. 111-112.

22 Respecto al viaje de latinoamericanos a Europa he seguido alguno de mis textos. Ver SANHUEZA, 2005a, 2005b, 2006a y 2006b. 
conformación de una perspectiva que estuviese encerrada bajo parámetros locales o regionales americanos. A pesar de que previo a la primera década del siglo XIX es posible visualizar las fisuras de lo que más tarde llegaría a ser la emancipación del Nuevo Mundo, en viajeros como José Antonio de Rojas (1742-1814), el contexto que rodeó al periplo europeo tendía a homogeneizar antes que diferenciar. La irrupción del mundo poscolonial alteró para siempre esta perspectiva iberoamericana. ${ }^{23}$

La búsqueda de una identidad continental conformó un tópico que, posterior al proceso político de Emancipación de España, se repitió una y otra vez en las preocupaciones de las élites hispanoamericanas. En tal proceso el viaje a Europa es reinterpretado como una forma de evaluación de lo propio a partir de una imagen que se estructuraba al entrar en contacto con el Viejo Continente. Se trata, pues, de un tipo de construcción de identidad desde la distancia que tomaba al espacio cultural europeo como punto de referencia, en el intento de encontrar desde allí el lugar que Hispanoamérica ocupaba dentro del concierto de las culturas mundiales. Se inaugura entonces un movimiento de inscripción de Hispanoamérica entre los otros continentes, hecho que no pasaba solamente por el mero reconocimiento consular por parte de los otros países, sino además por una verdadera instalación discursiva. Lo anterior significaba definir en qué medida lo americano tenía una existencia, una historia común y a la vez diferente, unos objetivos propios, unas particularidades. Sin embargo, dicha definición de identidad no se hacía prescindiendo de Europa. En efecto, el periplo europeo muchas veces fue interpretado como un acto bautismal de las nuevas naciones latinoamericanas pues era justamente en $\mathrm{Eu}-$ ropa - el faro cultural, la guía por excelencia - donde podía encontrarse el hombre o la mujer hispanoamericana desde las raíces de su cultura. Tal y como lo analiza David Viñas en Juan Bautista Alberdi para el caso argentino: las naciones hispanoamericanas delimitaban lo propiamente continental o nacional a partir de los modelos que el Viejo Mundo les ofrecía -

utilidad, necesidad de cambio, analogías en las que Europa es metro universal y punto de partida. Argentina ya empieza a ser pensada para Europa y por Europa y a significarse en sus hombres desde Europa. Progresismo, poner un país al día, estructurar un proyecto nacional, alcanzar el nivel de lo europeo. ${ }^{24}$

23 Respecto del viaje colonial ver: SANHUEZA, 2005a.

24 VIÑAS, 1974. Destacados del autor. 
La comparación, el establecer paralelismos entre uno y otro mundo se erguía como elemento central del viaje. El colombiano José María Samper en 1862 llegó a establecer todo un criterio evaluativo del grado de civilización, únicamente posible de identificar desde la distancia de la tierra natal puesto que:

la verdad no se adquiere completa sino por la comparación, y el espíritu debe abrazar la vida de los dos continentes [o sea, América y Europa] que trabajan de distinto modo en la obra de la civilización. ${ }^{25}$

De modo que Europa se visualizaba como el arribo, la única vía de acceso a la modernidad. Las nuevas repúblicas son imaginadas en el marco de la adscripción al molde que Europa imponía al resto del mundo. ¿En qué medida tal imaginario poscolonial fue determinado por el asunto de la pertenencia de América al mundo occidental? ¿En qué sentido se reflejó todo esto en la experiencia de los viajeros hispanoamericanos en el Viejo Mundo?

\section{Encontrando a occidente}

Los viajeros descubrieron el Viejo Mundo al mismo tiempo que hacían realidad un sueño y abrían la esperanza de un desarrollo que, al contacto con las urbes, se activaría en diferentes facetas, tanto personal como intelectual, tal y como Lilianet Brintrup lo ha destacado. ${ }^{26}$ El arribo a Europa marcaba un hito, un vuelco imborrable e irreversible. El chileno Benjamín Vicuña Mackenna, aun cuando llega al Viejo Continente por Inglaterra, realiza un camino directo a París, el primer objetivo, el polo de atracción. Ya en la capital francesa afirma:

Estaba ya en París, realizando el sueño de la mitad de mi vida y la imaginación adormecida otra vez en nuevos sueños de admiración y portento! Estaba en la capital del mundo, el corazón de la humanidad en que todo parece latir con las pulsaciones gigantescas que el espíritu de todos los pueblos envía a este centro de vida y de inteligencia. Miniatura del Universo, aquí existe todo lo creado. 27

De modo que, así como también lo menciona Juan Bautista Alberdi, la llegada a Europa generaba "un efecto maravilloso para nosotros los hijos del desierto".28

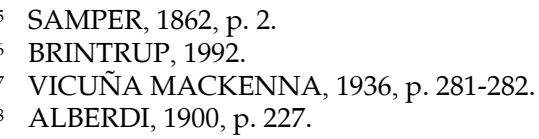


El efecto de la prima facie, del encantamiento, el embrujamiento de los latinoamericanos en Europa se explicaba en gran medida a partir del vínculo que éstos sentían con el Viejo Mundo, en tanto hacían parte, de alguna manera, de él: Europa como la cuna de la civilización americana. En este sentido el océano Atlántico era nada más que un accidente geográfico entre dos mundos que se advertían unidos. Por lo anterior es que, de algún modo, el viaje a Europa, más que un arribo, antes bien, era un retorno: la vuelta a los orígenes.

En un sentido, los orígenes se advertían desde los lazos consanguíneos, de ahí el interés por alcanzar la tierra de los antepasados. En 1853 Benjamín Vicuña Mackenna llega hasta Irlanda donde se reunió con sus antepasados familiares en Dublín. El sentimiento de retorno es explícito en él cuando recorre Irlanda, al ser dicho país la patria de sus ancestros lo que de alguna forma lo hacía sentirse también un poco parte de aquella tierra: "Pisaba por primera vez el suelo de la verde Erin, que era para mi una patria, si la patria es la tumba de los mayores [...] Que era más todavía, era mi hogar, mi sangre, mi nombre [...]". ${ }^{29}$ En este territorio no se podía describir como un simple viajero, no estaba permitido asumir la actitud de un observador que escudriña, racionaliza y evalúa. De ahí que el viajero chileno no busque hacer cálculos, ni comparaciones, ni siquiera observaciones. Acá los sentimientos, los sentidos agudizados ante lo que se contemplaba como parte de uno mismo, modificaban la trayectoria y la mirada del viajero. Vicuña Mackenna ahonda en la historia de su familia: recorre las casas de sus abuelos; conversa con primos y tíos: encuentra un hogar y una patria al mismo tiempo. El destino de unos pueblos condenados a vagar por las lejanías, ahora reunía a dos generaciones separadas por culturas e historias.

En otro aspecto, la cuestión de los orígenes devenían en un aspecto simbólico y de pertenencia a una civilización común. El argentino Domingo Faustino Sarmiento en 1846 lo deja establecido: "Siéntome que no soy huésped ni extranjero, [en Europa] sino el miembro de la familia que se acerca al hogar de sus antepasados". ${ }^{30}$ En el fondo, América se ubicaba en relación a Europa en una suerte de reconciliación del descendiente con sus ancestros: el Nuevo Mundo reconocía la paternidad de Europa, la deuda cultural, la herencia.

29 VICUÑA MACKENNA, 1936, p. 441.

30 SARMIENTO, 1849 , p. 76-77. 
Ahora bien, los viajeros latinoamericanos en Europa no sólo invocaron una ascendencia familiar o cultural, sino que también intentaron alcanzar el instante inicial que inauguró dichos vínculos: el Nuevo Mundo se miraba a sí mismo desde su eclosión primigenia. De esta forma el argentino Juan Bautista Alberdi llega en 1848 a Europa buscando aquellos fundamentos culturales que vinculaban a ambos mundos. El viajero se interroga: ¿cuándo podemos comenzar a hablar de América? ¿Cuál es el gesto histórico que la funda? A partir de lo anterior Alberdi buscó afanosamente encontrar aquel instante inicial: el arribo de Cristóbal Colón a América. En Génova el viajero no sólo sigue las huellas del descubridor, sino que también busca palpar su historia, sentirla como propia. Al acceder a los manuscritos en Génova declaró: "Al contemplar los caracteres trazados por la mano que gobernó el timón, que condujo al descubrimiento de un mundo nuevo, mis dedos se helaban de religioso entusiasmo". ${ }^{31}$

En Génova, Alberdi podía acceder a las fuentes mismas que posibilitaron la existencia de América tal y como él la conocía. Lo anterior explica el interés por encontrar registros históricos $\mathrm{u}$ objetos pertenecientes al descubridor genovés, como la pila donde éste se había bautizado. En efecto, el hallarse ante dicha pila bautismal instalaba un acceso al génesis del Nuevo Mundo: al principio de los principios. De ahí el nerviosismo, la solemnidad:

lo confieso, sentí erizarse mis cabellos, al pensar que estaba delante de la pila, en que había caído el agua santa que bañó el cráneo destinado a concebir un día el pensamiento de un mundo nuevo. Pero desgraciadamente mis ojos, que subían y bajaban en el examen de la memorable pieza, tropezaron con esta cifra, cincelada en el borde de la pila, 1676; y mi ilusión cayó muerta a manos de estos asesinos números, que no me dejaron ser feliz un minuto. ${ }^{32}$

La decepción se entiende al frustrarse el objetivo inicial, los deseos de alcanzar los vestigios que se desmoronaban al no corresponder las fechas, tal cual debían serlo. El mexicano Andrés Posada Arago asume similares posiciones al recorrer las tierras de Colón:

Dos objetos hallé que recuerdan al célebre navegante. El uno es un monumento de mármol, erigido en 1862, en una plaza no lejos del mar. Su estatua, sostenido por un pedernal adornado con apéndices que imitan popas y proas de navíos, tiene a sus pies la América,

1 ALBERDI, 1900, p. 71

32 ALBERDI, 1900, p. 80. 
representada en una india, postrada de rodillas y recibiendo de sus manos la cruz; abajo hay otras varias figuras alegóricas. El otro es una casa de cinco pisos, situada en la esquina que forma la Via Nuova de Ponticello al cruzarse con la de Morciento, la cual tiene en el muro exterior una inscripción que indica haber sido la habitación de Domingo Colón, padre de Cristóbal. Dicen que en ella nació este último; pero ningún otro detalle pudieron suministrarme el Ciceroni ni las personas que la habitaban. ${ }^{33}$

El viajero latinoamericano, no sólo asume su identidad y pertenencia al mundo occidental desde sus orígenes familiares o a partir de un momento inicial: al mismo tiempo encuentran su lugar, la Madre Patria, España. Si bien durante el tiempo cercano al proceso de Emancipación se buscó en América Latina la separación cultural de España, inevitablemente, afloraban sentimientos de pertenencia. El colombiano José María Samper claramente lo deja registrado en su periplo por la península ibérica: "Iba a visitar a España, la vieja y heroica patria de los fundadores de la mía - la patria de mis abuelos, de mi lengua y de todo lo que nutría mi espíritu". ${ }^{34} \mathrm{El}$ sentimiento de familiaridad se acentúa en el momento en que el viajero descubre los parecidos, las similitudes entre España y sus ex-colonias: desde allí se volvía a los orígenes. Así lo declara el chileno Luis Orrego Luco en Andalucía: "Veo aquí como una vuelta a Chile, algo de nuestros paisajes, cuando miro sus alamedas, sus bosques, sus verdes llanuras, las dehesas [...] Esa placidez y ese color del campo andaluz, tiene algo de los fundos chilenos del valle central". 35

Poco importaba si existían lazos consanguíneos directos como los de Vicuña Mackenna en Irlanda: España, de una manera u otra, era la patria de los americanos. El poeta nicaragüense Rubén Darío lo deja patente al afirmar en 1898, una vez que toca costas españolas: "Siento que estoy en casa propia; voy a España en una nave latina [...] De nuevo en marcha, y hacia el país maternal que el alma americana - americanoespañola [sic] - ha de saludar siempre con respeto, ha de querer con cariño honrado". ${ }^{36}$ Las heridas dejadas por la separación de España y sus colonias se cerraban en el preciso momento en que el viajero hispanoamericano asumía sus raíces, su propia historia.

Ahora bien, a pesar de que el viajero latinoamericano recorría Europa con la convicción del hijo pródigo, en tanto vehículo de acceso a la occidentalidad, existía, sin embargo, otra puerta de

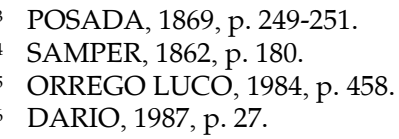


entrada, otra vía - más rápida - una manera de situarse en el Viejo Continente: el hacerse pasar por occidental. Muchos viajeros critican a otros latinoamericanos dada su tendencia a la imitación y búsqueda compulsiva de aceptación en Europa. Este fenómeno, denominado los trasplantados por el escritor chileno de fines del siglo XIX Alberto Blest Gana, originaba una suerte de esnobismo sudamericano, flor y enfermedad en París según lo afirmó el viajero chileno Luis Orrego Luco a fines del siglo XIX. Según este último, se advierte en los latinoamericanos, en especial en París, un afán casi obsesivo por hacer parte de Europa:

Los sudamericanos y, en especial, los chilenos gastaron fortunas en París: los Cousiño, los Errázuriz, los Urmeneta, los Ossa, y muchos otros, vivían en palacios y daban grandes comidas. Paseaban en elegantes carruajes en el Bois, pagaban queridas de lujo [...] Derrochaban torpe y estérilmente sus millones, sin lograr conocer nunca la verdadera vida del gran mundo, ni menos la vida intelectual de Europa. ${ }^{37}$

La búsqueda de reconocimiento por medio del dinero, paradójicamente, no hacía más que alejar a los viajeros latinoamericanos de su propósito, tornando sus gestos, actitudes, sociabilidad risibles y hasta despreciables. A lo anterior se le denominó en la época el rastacuerismo sudamericano: el ser lo que no se es; el vestirse de ropaje occidental y, sin embargo, continuar siendo otro, ajeno, marginal. Este fenómeno no puede ser entendido tan sólo como un mero acto imitativo, puesto que también encerraba el deseo de ser parte de un mundo, de una cultura que se percibía como superior. La novela Los transplantados de Alberto Blest Gana sólo viene a recoger este impulso casi obsesivo por aparentar: la periferia simulando ser centro. De allí la ridiculez, la mofa tal y como el propio Orrego Luco lo registra: "El rastacuerismo latinoamericano llegaba hasta el punto que un riquísimo boliviano compraba el flamante título de Príncipe de la Glorieta, que hacía sonreír hasta a los camareros del Maxim `s”. 38

\section{Europa: un Occidente decadente}

Ian Buruma y Aviahai Margalit denominan "occidentalismo" a la imagen de un orden occidental deshumanizado construido en los bordes de Europa: desde el mundo árabe y asiático. Lo anterior

ORREGO LUCO, 1984, p. 417-418.

38 Ibid., p. 419. Respecto al rastacuerismo ver: GONZALEZ, 2003 y 2004. 
corresponde a un sentimiento de hostilidad de aquellas culturas hacia occidente, respecto a las características que observan en sus ciudades: desarraigo, arrogancia, avaricia, decadencia y frivolidad cosmopolita. ${ }^{39} \mathrm{Al}$ respecto los viajeros latinoamericanos participaron, de alguna forma, de tales críticas: ¿Es Europa similar a la imagen construida al otro lado del Atlántico? ¿Es acaso este centro del mundo, cuna de la civilización, algo más que un cúmulo de bellos edificios, librerías y universidades? Así, el viajero chileno Benjamín Vicuña Mackenna en París define la ciudad como un mosaico cultural: un monstruo de mil colores, incontrolable, cosmopolita por esencia. Allí constata el viajero cómo la moda y el dinero son los verdaderos patrones que modelan la vida occidental. Las apariencias, la ostentación, se yerguen por sobre consideraciones espirituales, supuestamente propias de un mundo civilizado. Por ello París no resultaba aquel sueño visto desde la lejanía. Algo acá no funcionaba. El sueño de los latinoamericanos por el Viejo Mundo se desarmaba ante la Europa real. ¿Qué hacer ante ello? Dicha cuestión llegó a ser hasta dolorosa en el citado Vicuña Mackenna:

Yo me entregaba sin reserva a mis ilusiones al pisar los sitios en que desde tan lejos las había bebido, pero un sacudón violento debía pronto despertarme [...] Yo me figuraba un París grande y bello, juzgándolo por su reflejo como se juzga al sol por sus rayos [...] Pero cuando apenas dejaba la Estación del camino de hierro para dirigirme al otro lado del Sena, y vi las calles y casas y gente y bodegones, $\mathrm{y}$ veredas enlodadas [...] cuando pasaba por la plaza del Carrusel y veía el Louvre convertido en escombros [...] por pueril que fuera mi desencanto, tuve más de una vez la tentación de apearme del fiacre que me llevaba y preguntar al cochero si aquel era verdaderamente París. ¡El París de mis ilusiones!. 40

La Europa verdadera contrastaba fuertemente con la de las ilusiones. Un mundo construido sobre la base de reflejos, mitos, se derrumbaba. La belleza y grandeza de París de pronto era reemplazada por una suerte de torbellino: un caos donde todo se mezclaba; todo presentándose al mismo tiempo, golpeando los sentidos, tumultuoso, voraz, revuelto. Un pedazo de mundo de pronto ser había desplomado y convertido antiguas certezas en meras ilusiones. América Hispana bruscamente despertaba de su sueño occidentalista.

BURUMA/MARGALIT, 2004, p. 11.

40 Ibid., p. 282-283. 
En Londres los viajeros refuerzan esta noción occidentalista de una Europa fría, materialista y calculadora. El colombiano José María Samper en dicha ciudad lo describe:

En este país del comercio, de la especulación, de la vida práctica, de los espíritus serios [...], glacialmente calculadores, el tiempo es el capital más valioso [...]. Cada palabra sale medida, tasada por los labios [...]; cada hombre es una locomotiva, un tren expreso; cada acción es un cálculo; el ser humano es un número hecho carne y hueso. ${ }^{41}$

El viajero incluso va más allá, cuestionando si este mundo representaba realmente el progreso, la civilización: “¿De qué sirve toda esta grandeza deslumbradora, si ella es el testimonio de un malestar profundo consistente en las más crueles y dolorosas desigualdades? ¿Es esta la civilización? ¿Es este el progreso o más bien la decadencia?".42 Evidentemente al viajero le impactan las condiciones de vida del Londres de 1862, pero al mismo tiempo tales características las toma como un símbolo del mundo moderno, advirtiendo los peligros de considerar a dicho país en un modelo a seguir. ${ }^{43}$

Particularmente esta visión de una Europa decadente se hacía patente en los viajeros a partir del viaje a España. En este sentido, si bien España representaba los orígenes para los latinoamericanos también era el de un mundo que se había quedado atrás, un "castillo feudal" en palabras de Rubén Darío: un lugar donde primaba "una producción enclenque y falsa, desconocimiento del progreso mental del mundo, iconoclasticismo infundado o ingenuidad increíble, subsistente fe en viejos y desechos fetiches". ${ }^{44}$ No solamente la decadencia española correspondía a un anclaje en tradiciones anquilosadas y miradas nostálgicas, también el propio pueblo constituía la expresión misma del atraso, la barbarie, la incivilización: "no hay duda de que colectivamente el español es la más clara muestra de regresión a la fiereza primitiva". ${ }^{45}$ Esta decadencia de España pasaba por la pérdida de su supremacía, su imperio, tornando sus actuales circunstancias un mero reflejo nostálgico de lo que alguna vez fue. El viajero chileno Luis Orrego Luco, asistiendo a una gala de la Ope-

41 SAMPER, 1862, p. 75.

42 Ibid., p. 98.

43 En muchos viajeros, como en el propio Samper, existía el temor de que este mundo materialista, decadente, de alguna forma afectara a los compatriotas que arribaban al Viejo Mundo. De allí que, una y otra vez, advirtieran de los peligros y tentaciones a los que se podían ver afectados los recién llegados. Ver SAMPER, 1869, p. 108-127.

44 DARIO, 1987, p. 45-46.

45 Ibid., p. 119. 
ra en Madrid, constata un espectáculo cortesano lejano a los días de gloria y fama:

Durante un largo rato oí así el anuncio de títulos y títulos. Fue cosa de nunca acabar. Porque a veces seguía un desfile de señores viajas, gordas y feas, muy enjoyadas, pero desprovistas, en su mayoría, de distinción, de gracia, de la simpatía acogedora de nuestras élites americanas. Y sentí una gran decepción de la nobleza de nuestra Madre Patria. Me pareció, quizá por eso, algo ridículo este primer desfile de tantos excelsos títulos y grandezas. ${ }^{46}$

La Europa moderna, el modelo occidental, era percibido por los viajeros latinoamericanos desde sus claroscuros: sus límites de pronto eran advertidos desde la experiencia misma de recorrerla; los efectos nocivos a partir de sus manifestaciones más evidentes; sus posibilidades desde el rescate de sus bondades. A partir del viaje a Europa, América Latina podía encontrar un lugar dentro de occidente, una vez que había palpado en carne propia las bases de su cultura. ¿Qué hacer ante tales constataciones? ¿Abandonar el modelo occidental? ¿Buscar uno propio?

\section{América Latina: ¿otro Occidente?}

Este darse cuenta de los límites del mundo occidental, el abandonar el prisma idealizante, implicaba un redescubrimiento poscolonial del Viejo Mundo.

En primer lugar, los viajeros advierten los cuestionamientos que Europa realiza respecto de la real adscripción del Nuevo Mundo al discurso occidental. En este sentido, el desconocimiento que existía en Europa sobre América Latina era interpretado por los viajeros como un recurso europeo, en pos de definir los límites de Occidente, que dejaba fuera a la porción hispana del Nuevo Mundo, tal y como Hegel lo había hecho años atrás. En efecto, la constatación de la inserción conflictiva de los latinoamericanos a Occidente llegó a ser evidente al ser objeto éstos de la exclusión que los habitantes del Viejo Mundo hacían de ellos. A los viajeros les llama la atención en qué sentido los europeos no lograban convencerse de que los latinoamericanos formasen parte del universo cultural de occidente. De allí que el viajero colombiano José María Samper, por la década de 1850, no deja de asombrarse ante la sorpresa que su perfecto francés y conocimientos causaban en el salón literario de Lamartine. Este no reconocimiento de pertenencia, que

46 ORREGO LUCO, 1984, p. 445. 
por muchos viajeros fue interpretado tan sólo como falta de conocimiento e ignorancia (por ejemplo, la chilena Maipina de la Barra), dio pie a una reformulación de lo que hasta antes del periplo europeo se sostenía. Los deseos hispanoamericanos de ser parte del horizonte cultural europeo se vieron frustrados por la experiencia misma de sus viajes. Éstos explicitaban su decepción, su malestar, por una cultura que no los reconocía como parte integrante del mundo occidental, civilizado. Aquella vinculación "natural" que sentían los viajeros antes de conocer el Viejo Continente - América como parte de una Europa transplantada al Nuevo Mundo - se había deshecho. Será justamente a partir de dicha constatación desde donde los hispanoamericanos comiencen a construir un otro occidente, percibido por éstos como una superación del occidentalismo eurocéntrico.

Muchos viajeros buscaron reorganizar y situarse en el mapa del mundo ante la constatación de una Europa enfrentada desde la experiencia de viaje y no solamente a partir de un sueño del Nuevo Mundo. Domingo Faustino Sarmiento se pregunta: ¿Cuál es nuestra real posición frente al mundo occidental? ¿Dónde podemos ubicarnos ahora que hemos conocido la Europa real?:

basta, con efecto, para darnos una idea de las costumbres i modos de ser orientales; que en cuanto al Oriente, que tantos prestijios tiene para el europeo, sus antigüedades i tradiciones son letra muerta para el americano, hijo menor de la familia cristiana. Nuestro Oriente es la Europa, i si alguna luz brilla más allá, nuestros ojos no están preparados para recibirla, sino a través del prisma europeo. ${ }^{47}$

Claramente los americanos no eran orientales, pues este espacio representaba para ellos lo ajeno, lo distante: letra muerta. Ahora bien, al afirmar Nuestro Oriente es la Europa, Sarmiento instalaba una bidimensionalidad. Por un lado era posible tomarlo en un sentido puramente territorial: en la representación cartográfica Europa era para América, lo que oriente para Europa. ${ }^{48}$ Sin embargo, ello también tenía su dimensión simbólico-cultural puesto que así como Oriente, que tantos prestijios tiene para el europeo, había traspasado al Viejo Mundo sus antigüedades $i$ tradiciones, lo mismo hacía este último con respecto al Nuevo Mundo. Europa como oriente era el punto cardinal a partir del cual se pensaba el continente americano. Lo anterior declaraba la occidentalidad de America, pero de un otro occidente. Este otro occidente concebía a Europa

47 SARMIENTO, 1849, p. 172. Se ha mantenido la grafía original.

48 MONTALDO, 1996. 
como el oriente, en tanto que conformaba la orientación, el archivo cultural, la memoria histórica desde donde el Nuevo Mundo construía una nueva occidentalidad.

Esta noción de nueva occidentalidad ha sido analizada en relación a la estadía inglesa de Andrés Bello en tanto post-occidentalidad. En efecto, según Álvaro Kaempfer, Bello en su Alocución a la Poesía escrita en Londres en 1826 destaca el agotamiento poético de Europa. Este agotamiento "le abriría a América el mundo de Colón su grande escena por medio de una ecuación poética que redefine el nexo entre Occidente e Historia". ${ }^{49}$ La poesía le ofrecía las coordenadas a Bello lo que le permitía, en la interpretación de Kaempfer, refundar la posición del Nuevo Mundo frente al Viejo Mundo. De esta forma, América no conformaba una simple continuidad de Europa, sino más bien, su superación. Las experiencias de Bello en Europa se expresarían en el poema, al destacar la emergencia histórica de América frente al agotamiento estético de Europa. ${ }^{50}$ De este modo, Bello construye un nuevo referente geocultural: un occidente trasatlántico, posteuropeo. América se mira desde el otro lado del Atlántico en un movimiento que, a la vez que funda, busca retornar a los orígenes, al espacio primigenio. A lo que se alude es a una mítica y remota emergencia que le permitiría a América no simplemente reproducir lo acontecido en Europa, sino más bien reinventar un occidente posteuropeo. ${ }^{51}$ Dicha reinvención sólo habría sido posible en tanto Bello se trasladó a Europa, en la medida en que su producción poética se vio influenciada por sus experiencias de viaje, el desarraigo y la distancia de sus orígenes.

\section{Conclusiones}

El viaje de latinoamericanos a Europa, sin duda, rebasó sus objetivos iniciales. Junto con hacer estudios, convertir al Viejo Continente en una patria del exilio o ejercer representación diplomática, los latinoamericanos intentaron organizar culturalmente el mundo conocido: ubicar a América; plantearse frente Europa. De ahí que no se puede analizar sus experiencias tan sólo destacando el aspecto imitativo, de asombro ante el mundo moderno o de rechazo. El contexto que guiaba sus miradas los ponía al umbral de algo nuevo: ante la disyuntiva de seguir o no unos modelos,

KAEMPFER, 2004, p. 470.

Ibid., 480.

51 Ibid. 
frente a la contemplación de unos orígenes, desde un espacio a partir del cual refundar Occidente. De alguna manera, el viaje a Europa develó las complejidades del proceso de reorganización postcolonial posterior a la emancipación de España. De esta forma, el estudio de estos desplazamientos allende el océano denota que dicha reorganización no consistió tan solo en generar un marco jurídico o económico a las nuevas naciones: también había que encontrarles un puesto en el mundo.

El viaje enfrentaba a los viajeros latinoamericanos, como en juego de espejos, frente a sí mismos desde una exterioridad. En este sentido, Europa hacía las veces de filtro, visor, y perspectiva ineludible. Tal como lo expresa Domingo Faustino Sarmiento: América no podía ver más allá sin recurrir al prisma europeo. La existencia misma de América Latina era tributaria de la expansión trasatlántica europea. Esta constatación, surgida desde la experiencia de viajes y no desde el escritorio americano, era lo que le permitía a los latinoamericanos redefinir el curso de occidente. Así, y sólo así, el Nuevo Mundo lograba encontrarse desde sus orígenes consigo mismo. De esta manera, América se separaba simbólicamente de su tutela colonial tal y como lo había hecho decenios antes por las armas. El Nuevo Mundo dejaba de ser nuevo para devenir en un nombre propio.

\section{Referencias bibliograficas}

ALBERDI, Juan Bautista. Viajes y descripciones. Buenos Aires: W. M. Jackson, 1900.

BHABHA, Homi. The Location of Culture. London: Routledge, 1994.

BLAUT, James. The colonizer's Model of the World. Geographical Diffusionism and Eurocentric History. New York: The Guilford Press, 1993.

BRINTRUP, Lilianet. Viaje y escritura. Viajeros Románticos chilenos. New York: Peter Lang, 1992.

CARMAGNANI, Marcello. El otro occidente. América Latina desde la invasión europea hasta la globalización. Mexico: Fondo de Cultura Económica, 2004.

CASTRO-GÓMEZ, Santiago. Latinoamericanismo, modernidad, globalización. Prolegómenos a una crítica poscolonial de la razón. In: Santiago Castro-Gómez/Eduardo Mendieta (eds.). Teorías sin disciplina (latinoamericanismo, poscolonialidad y globalización en debate. México: Miguel Ángel Porrúa, 1998.

CASTRO-GÓMEZ, Santiago. Crítica de la razón latinoamericana. Barcelona: Puvill Libros, 1996. 
CORONIL, Fernando. Beyond Occidentalism: Toward Nonimperial Geohistorical Categories. Cultural Anthropology, vol. 11, Arlington, febrero 1996.

CHARTIER, Roger. El mundo como representación. Historia cultural: entre práctica y representación. Barcelona: Gedisa, 2002.

DARIO, Rubén. España Contemporánea. Barcelona: Lumen, 1987.

DUSSEL, Enrique. Posmodernidad y transmodernidad: diálogos con la filosofía de Gianni Vattimo. México: Universidad Iberoamericana, 1999.

DUSSEL, Enrique. The invention of the Americas. Eclipse of "the Other" and the Myth of Modernity. New York: Continuum Publishing, 1995.

FEY, Ingrid E./RACINE, Karen (eds.). Strange Pilgrimages. Exile, Travel, and National Identity in Latin America. Wilmington: Scholarly Resources (Jaguar books on Latin America, ํㅡㄹ) 2000.

GERBI, Antonello. La Disputa del Nuevo Mundo. Historia de una polémica. 17501900. México: Fondo de Cultura Económica, 1993 (edición corregida y aumentada del original en italiano de 1955).

GONZÁLEZ, Francisco Javier. Sueños y realidades de los latinoamericanos en París a fines del siglo XIX. ¿Viajeros ilustrados o rastaquouères marginados?". Bicentenario, Revista de Historia de Chile y de América, p. 69-98, 2004.

GONZÁLEZ, Francisco Javier. Aquellos años franceses. 1870-1900. Chile en la huella de París. Santiago de Chile:Taurus, 2003.

HEGEL, G. W. F. Vorlesungen über die Philosophie der Geschichte. In: Werke in zwanzig Bänden (Lecciones de Filosofía Universal). Frankfurt am Main: Suhrkamp Verlag, 1972, vol. 12.

KAEMPFER, Álvaro. América hipotética, post-occidental e inconclusa en Alocución a la Poesía (1823) de Andrés Bello. Revista de Estudios Hispánicos, 38.3, 2004, p. 469-485.

MARTÍNEZ, Frédéric. El nacionalismo cosmopolita. La referencia europea en la construcción nacional en Colombia. 1845-1900. Bogotá: Banco de la República, Instituto Francés de Estudios Andinos, 2001.

MIGNOLO, Walter. La colonialidad a lo largo y a lo ancho: el hemisferio occidental en el horizonte colonial de la modernidad. In: Edgardo Lander (comp.). La colonialidad del saber; eurocentrismo y ciencias sociales. Buenos Aires: CLACSO, 1993.

MIGNOLO, Walter. Postoccidentalismo: el argumento desde América Latina. Santiago Castro-Gómez. Teorías sin disciplinas. México: Miguel Angel Porrúa, 1998.

MIGNOLO, Walter. Local Histories/Global Designs. Coloniality, Subaltern Kwonledge and Border Thinking. Princeton: Princeton University, 2000.

MIGNOLO, Walter. The Darker Side of the Renaissance. Literacy, Territoriality and Colonization. Michigan: University of Michigan Press, 1995. 
NÚÑEZ, Estuardo. Viajeros Hispanoamericanos (Temas Continentales). Caracas: Biblioteca Ayacucho, 1990, tomo 140.

O'GORMAN, Edmundo. La invención de América. México: Fondo de Cultura Económica, 2004 (primera edición: 1958).

PIETRI, Uslar. La creación del Nuevo Mundo. México: Fondo de Cultura Económica, 1992.

POSADA ARANGO, Andrés. Viaje de América a Jerusalén. París: Imprenta A. E. Rochet, 1869.

QUIJANO, Aníbal. La colonialidad del poder y la experiencia cultural latinoamericana. In: Roberto Briceño León/Heinz R. Sonntag (eds.). Pueblo, época y desarrollo: Caracas: Nueva Sociedad, 1998.

RICOEUR, Paul. Geschichtsschreibung und Repräsentation der Vergangenheit. Berlín: LIT, 2002.

SAID, Edward, Orientalism. Western conceptions of the Orient. New York: Pantheon Books, 1978.

SAMPER, José María. Viajes de un colombiano en Europa. París: Imprenta de E. Thunot y Cía., 1862.

SAMPER, José María. Miscelánea. París: Denne, 1869.

SANHUEZA, Carlos. Viajes e identidad. La experiencia de la distancia en la construcción de lo propio. Patrimonio Cultural, DIBAM, Santiago de Chile, № 33 Año IX, Primavera 2004, p. 28-29.

SANHUEZA, Carlos. De la periferia colonial al centro del Imperio. Viajeros hispanoamericanos en las cortes españolas durante el siglo XVIII. In: Renate Pieper/Peer Schmidt (eds.). Latin America in the Atlantic World. El mundo atlántico y América Latina (1500-1850). Essays in honor of Horst Pietschmann. Colonia: Bölhlau Verlag, 2005a, p. 213-220.

SANHUEZA, Carlos. From the southern hemisphere to the Old World. Travel accounts of Chileans in Europe and representation of national identity in the 19th CenturyIn: Richard Weiner/Raúl Galoppe (eds.). A fine line: explorations in Subjectivity, Borders, and Demarcation. New York/Toronto/Oxford: University Press of America, 2005b, p. 47-68.

SANHUEZA, Carlos. El problema de mi vida: ¡soy mujer! Viaje, mujer y sociedad. Rafael Sagredo/Cristián Gazmuri (eds.). Historia de la vida privada en Chile. El Chile moderno. Santiago de Chile: Taurus, 2006a, tomo II, p. 333-347.

SANHUEZA, Carlos. Chilenos en Alemania y alemanes en Chile. Viaje y nación en el siglo XIX. Santiago de Chile: DIBAM/LOM, 2006b.

SARMIENTO, Domingo Faustino. Viajes en Europa, Africa i los Estados Unidos. Santiago de Chile: Imprenta J. Belin, 1849.

VICUÑA MACKENNA, Benjamín. Páginas de mi diario durante tres años de viaje. 1853-1854-1855. Santiago de Chile, 1936 (primera edición: 1856). 
VICUÑA, Manuel. La belle epoque chilena. Santiago de Chile: Sudamericana, 2001.

VIÑAS, David. Literatura argentina y realidad política. De Sarmiento a Cortázar. Buenos Aires: Ediciones: Siglo XX, 1974 (2. edición).

WALLERSTEIN, Immanuel. The Modern World-System. New Cork: Academic Press Inc., 1974-1989 (3 vols.).

ZEA, Leopoldo. América como conciencia. México: UNAM, 1972.

ZEA, Leopoldo. Discursos desde la marginación y la barbarie. México: Fondo de Cultura Económica, 1992 (tercera reimpresión).

ZEA, Leopoldo. El pensamiento latinoamericano. Barcelona: Ariel, 1976.

Recebido em 3 de agosto de 2007. 